\title{
Tarkkaan rajattuja näkökulmia yhteisvaluuttaan
}

Sixten Korkman: Euro - valuutta vailla valtiota. Taloustieto, Helsinki 2013

Jussi Ahokas

Pitkän virkamiesuran Suomessa ja Euroopan unionissa tehnyt ja viime vuonna Elinkeinoelämän Tutkimuslaitoksen johdosta eläköitynyt Sixten Korkman (VTT) on kirjoittanut mielenkiintoisen kirjan eurosta ja Euroopan talous- ja rahaliitosta (EMU). Ajankohtaisempaa aihetta talousteoriaa ja -politiikkaa käsittelevälle tietokirjalle on vaikea löytää euroalueen kärvistellessä jo viidettä vuotta taloudellisessa ahdingossa.

Korkman ei käsittele kirjassaan ainoastaan viimeaikaisia talousongelmia, vaan kartoittaa kiitettävän laajasti eurojärjestelmän historiallisia vaiheita sekä kulttuurista, poliittista ja talousteoreettista perustaa. Lisäksi hän esittää ehdotuksensa EMU:n rakenteellisten ongelmien korjaamiseksi. Motiivina kirjalle on toiminut Korkmanille 16 vuotta sitten Oulussa Suomen EMU-jäsenyyttä käsitelleessä yleisötilaisuudessa esitetty kysymys, joka jäi vaivaamaan häntä: "miten sieltä (EMU:sta) pääsee pois?"

Ennen kuin Korkman vastaa kysymykseen, hän käy syvällisesti läpi EMU:n historiaa ja pohtii EMU:n perustamisen syitä. Hänen tulkintansa on, että talous- ja rahaliitto on ensisijaisesti poliittinen projekti ja osa toisen maailmansodan jälkeistä Euroopan integraatioprosessia. Korkman antaa tilaa myös talouspoliittiselle ajattelulle selittäessään EMU:n syntyä. Hän korostaa Euroopassa jo vuosisatoja vallinnutta ajatusta kiinteiden valuuttakurssien autuudesta sekä 1980-luvulla yleistynyttä näkemystä, jonka mukaan uskottava rahapolitiikka edellyttää keskuspankin itsenäisyyttä.

Korkman tekee kirjassaan mielenkiintoisen erottelun EMU:n poliittisiin ja taloudellisiin perusteluihin. Taloudellisilla perusteluilla hän viittaa alun perin Robert Mundellin (1961) kehittämään optimaalisen valuutta-alueen teoriaan (OVT), jonka pohjalta euroalueen hyötyjä ja haittoja 1990luvulla punnittiin. Jo tuolloin monet taloustieteilijät varoittivat, ettei euroalue muodosta optimaalista valuutta-aluetta, jonka edellytyksenä on suuri tuotannontekijöiden ja valmistettujen hyödykkeiden liikkuvuus, palkkojen ja hintojen yhtäläinen joustavuus, alueiden eroa tasoittavat tulonsiirrot sekä 
suhdannevaihteluiden samarytmisyys.

Korkman yhtyy jälkikäteisarvioinnissaan tähän näkemykseen ja päättelee, ettei kyseisen taloudellisen näkemyksen pohjalta nykyisenkaltaista EMU:a olisi koskaan pitänyt muodostaa. Hän kuitenkin myöntää, että myös taloudellisen tai taloustieteellisen harkinnan kautta oli mahdollista päätyä puoltamaan EMU:n perustamista. Korkman kuvaa kirjassaan, kuinka OVT:n klassisempaa "mikroteoreettista" tai ehkä oikeammin rahateoreettista puolta painottamalla euroalueen hyötyjen voitiin katsoa nousevan sen haittoja suuremmiksi.

Kuten Charles Goodhart (1998) on osoittanut, OVT nojaa tältä osin niin kutsuttuun metallistiseen rahateoriaan tai näkemykseen rahasta. Tiivistettynä metallistinen teoria sanoo, että raha on taloudessa vaihdon väline, joka on syntynyt markkinaperusteisesti, kun taloudelliset toimijat ovat pyrkineet tehostamaan käymäänsä vaihtokauppaa. Ensin vaihdon välineeksi valikoitui hyödykeraha, kuten suola tai karja, mutta lopulta jalometallit korvasivat nämä ylivertaisten ominaisuuksiensa, kuten jaettavuuden, kestävyyden ja siirrettävyyden ansiosta. Kun vaihdanta laajeni, metallirahasta tuli kirjaimellisesti taakka. Tästä syystä käyttöön otettiin seteliraha, joka korvasi metallirahan kiertävänä vaihdon välineenä.

Talousteorian historiaa tutkinut itävaltalainen taloustieteilijä Joseph Schumpeter katsoi metallismin perinteen yltävän aina Aristoteleeseen asti. Schumpeter (1954, 288-292) tulkitsi klassisen taloustieteen isän Adam Smithin juurruttaneen metallismin lopullisesti valtavirtaiseen taloustieteelliseen ajatteluun. Schumpeterin mukaan teoreettisesta metallismista on olemassa käytännön sovellus, joka ottaa kantaa pankkitoiminnan ja keskuspankkitoiminnan järjestämiseen sekä rahapolitiikan perusteisiin. Käytännöllisen metallismin perusperiaate on, että rahan tai valtion valuutan vaihtosuhde tulee kiinnittää tietyn hyödykkeen arvoon eikä niiden vaihdettavuutta hyödykkeeseen tule millään tavalla rajoittaa. Tällä tavalla rahan liikkeellelaskijan on rajoitettava rahan määrää taloudessa, jotta liian suuresta rahan määrästä johtuva inflaatio voidaan estää. Tämä näkemys perustuu puolestaan klassiseen rahan kvantiteettiteoriaan. Metallistinen ajattelutavan voidaan nähdä olevan myös edellä mainitun Euroopassa vahvana eläneen kiinteiden valuuttakurssien uskon taustalla.

Myös OVT:ssa yhteisvaluuttaan siirtymisen nähdään johtavan vaihdannan tehostumiseen. Ajatuksena on, että valtioiden omista valuutoista 
luopuminen johtaa sellaisen vaihdon välineen syntymiseen, joka oleellisesti vähentää liiketoimikustannuksia ja parantaa markkinoiden toimintaa. Pidemmällä tähtäimellä tällä on merkittäviä positiivisia vaikutuksia talouden kasvuun, investointeihin sekä työllisyyteen. Jos vaihdannan tehostumisen oletetaan muuttavan laajemminkin taloudellisten toimijoiden käyttäytymistä ja parantavan markkinamekanismin toimintaa vaikkapa rahoitus- ja työmarkkinoilla, hyödyt kasvavat entistä suuremmiksi.

Esimerkiksi yhdysvaltalaiset taloustieteilijät Andrew Rose ja Jeffrey Frankel (1997) esittivät ennen EMU:n perustamista niin kutsutun endogeenisen konvergenssin teorian pohjalta, että vaikka tietty valuutta-alue ei sitä perustettaessa olisi optimaalinen valuutta-alue, yhteisvaluutan käyttöönoton jälkeen se alkaisi muuttua sellaiseksi. Kun eurojärjestelmään luotiin vielä finanssipoliittiset säännöt sekä perustettiin itsenäinen keskuspankki, joiden myötä valtioiden velkaantumista ja rahan määrän kasvua taloudessa pyrittiin hillitsemään käytännöllisen metallismin oppien mukaisesti, OVT:n osoittamat eurojärjestelmän alkutilanteessa havaitut makrotaloudellisten rakenteiden puutteet voitiin sivuuttaa perustellusti ja edelleen kyseisestä teoriasta kiinni pitäen.

Tästä näkökulmasta Korkmanin kirjassaan useaan otteeseen toistama väite, jonka mukaan EMU:a perustettaessa "poliittiset tarkoitusperät" johtivat "taloudellisten näkökohtien sivuuttamiseen ja ongelmien vähättelyyn", onkin erittäin kiinnostava. Ajatteleeko Korkman, että tietyt taloudelliset perustelut - ja vieläpä klassisesta talousajattelusta johdetut perustelut - olisivat olleet jollain tapaa poliittisesti värittyneitä? Koska hän ei halua myöntää taloustieteilijöille tyypilliseen tapaan tieteenalansa poliittisuutta, hän muotoilee asian siten, että tiettyihin EMU:n muodostamista puoltaviin teorian osiin saattoi liittyä toiveajattelua ja näin tietyistä oletuksista, kuten EMU:n muuttumisesta optimaaliseksi valuutta-alueeksi sen perustamisen jälkeen, saattoi tulla liian optimistisia. Joka tapauksessa kyseenalaistamalla talousteorian objektiivisuuden Korkman hämärtää aiemmin tekemäänsä erottelua EMU:n taloudellisiin ja poliittisiin perusteisiin.

On kiinnostavaa, että Korkman viittaa kirjassaan myös sellaisiin eurojärjestelmän ongelmiin, joita edellä kuvatussa OVT:ssa ja siten EMU:n "taloudellisessa" arvioinnissa ei lainkaan otettu huomioon. Hän ei kuitenkaan eksplisiittisesti viittaa näistä ongelmista jo 1990-luvulla ennen EMU:n perustamista varoittaneisiin taloustieteilijöihin. Korkmanin kirjassa monia 
esimerkiksi Charles Goodhartin (1997), L. Randall Wrayn (1998) ja Wynne Godleyn (1992 sekä 1997) ennalta näkemiä eurojärjestelmän ongelmia käsittelevän alaluvun otsikko on paljon puhuvasti "Ennakoimattomat ongelmat". Epäselväksi jää, lukeeko Korkman niin kutsuttua chartalistista EMU-kritiikkiä lainkaan osaksi EMU:a koskevia taloudellisia perusteluja.

Schumpeter määritteli chartalismin metallismin vastakohdaksi. Chartalismi on siis teoria, jonka mukaan rahan perustana ei ole tietty metalli tai muu hyödyke ja rahapoliittinen käytäntö, jonka mukaan rahan tai valuutan vaihtosuhdetta ei tulisi sitoa minkään hyödykkeen hintaan. Kun metallistit, ja myös Korkman kirjassaan, pitävät rahaa vaihdon välineenä, chartalistit pitävät sitä maksuvälineenä.

Chartalistit näkevät rahatalouden muodostuvan velkasuhteiden hierarkiasta ja rahataloudellisen toiminnan olevan velkasuhteiden selvittämistä. Lisäksi he ymmärtävät valtion valuutan olevan taloudessa viimekätinen maksuväline, mikä takaa sen, ettei omalla kelluvalla valuutalla operoiva valtio voi koskaan ajautua maksukyvyttömäksi. Viimekätisen maksuvälineen valtion valuutasta tekee chartalistisen teorian mukaan valtion verotusoikeus. Verotusoikeuden seurauksena kaikilla kansalaisilla on tarve pitää hallussaan valtion valuuttaa, koska se on ainoa verojen maksamiseen kelpaava väline. Chartalistisen kritiikin mukaan valtion erottaminen valuutasta siten, että se menettää valuutan liikkeellelaskuoikeuden, voi johtaa kriisiherkässä rahataloudessamme suuriin ongelmiin.

EMU:ssa valtiot hyväksyvät maksunsa euroissa ja tekevät siten eurosta viimekätisen maksuvälineen talousalueella. $\mathrm{Ne}$ eivät voi kuitenkaan enää suorittaa maksujaan laskemalla liikkeelle uutta valuuttaa, sillä tämä oikeus on siirretty itsenäiselle EKP:lle. Ne joutuvat siis hankkimaan eurovaluuttaa joko verottamalla tai rahoitusmarkkinoilta lainaamalla, minkä vuoksi niiden maksukyky edellyttää riittäviä verotuloja sekä markkinaluottamusta. Kun kapitalistiselle talousjärjestelmälle tyypillisessä velkakriisissä verotulot romahtavat ja markkinoiden luottamus katoaa, on maksukyvyttömyys odotettu lopputulema. Tällaisessa tilanteessa valtio ei voi enää kuluttaa ja nostaa elvytyksellä rahataloutta lamasta. Syntyy itseään vahvistava negatiivinen kierre. Korkmanin kirjan otsikkoa mukaillen chartalistien esittämän yhteisvaluutan ja eurojärjestelmän kritiikin voikin kirjoittaa muotoon: "Euro - valtiot ilman valuuttaa".

Koska Korkman ei käsittele kirjassaan chartalistista kritiikkiä, häneltä jää 
esittämättä EMU:n syntyhistorian kannalta todella kiinnostava kysymys: olisiko EMU:a perustettu nykyisessä muodossaan, jos kyseinen kritiikki olisi tunnettu laajemmin ja valtioiden maksukyvyn menettämisestä seuraavat ongelmat olisi tiedostettu. Esimerkiksi Suomen EMU-jäsenyys, johon kansalaiset suhtautuivat lähtökohtaisestikin epäillen, olisi voinut jäädä toteutumatta, jos Jukka Pekkarisen työryhmä olisi vuonna 1997 varoitellut suhdanneongelmien mahdollisen syvenemisen lisäksi myös Euroopan laajuisen velka- ja pankkikriisin mahdollisuudesta ja sen vaikutuksista suomalaiseen talouspolitiikkaan sekä tulonsiirtoihin eteläisiin jäsenmaihin.

EMU:n syntyhistorian kuvaamisen jälkeen Korkman käsittelee kirjassaan lyhyesti eurokriisiä, jonka syynä olivat hänen mukaansa juuri edellä mainitut odottamattomat ongelmat eli velkakriisi ja heikot EMU-instituutiot. Korkman kuitenkin uskoo, että kriisi olisi ollut vältettävissä paremmalla sääntöjen noudattamisella ja markkinakurilla. Näin ainakin julkinen velkaantuminen, mutta mahdollisesti myös yksityisen velkakuplan syntyminen useassa eteläisessä euromaassa olisi voitu estää. Valitettavasti Korkman ei pohdi kovinkaan syvällisesti, millaiset vaikutukset talouskasvuun ja työllisyyteen kovemmalla talouskurilla olisi ollut euroalueella euron ensimmäisen ja varsin menestyksekkään vuosikymmenen aikana.

Kuvattuaan lyhyesti tähän mennessä toteutettuja kriisinhoitotoimenpiteitä, Korkman palaa hänelle keväällä 1997 esitettyyn kysymykseen. Korkmanin mukaan yksittäisen valtion on erittäin vaikea päästä pois EMU:sta, minkä vuoksi järjestelmä on korjattava sisältä päin. On helppo yhtyä hänen näkemykseensä siitä, että eurojärjestelmän purkamiseen liittyy suuri määrä taloudellisia ja yhteiskunnallisia riskejä.

Lopulta Korkmanin työkalupakista löytyy kuitenkin yllättävän vähän uusia avauksia. Hän tyrmää yhteisvastuullisuuden lisäämisen, haluaa lisätä markkinakuria eli rahoitusmarkkinoiden valtaa yli valtioiden ja kannattaa tiukkaa budjettikuria jäsenmaissa. Pitkän aikavälin vakautta lisäävänä institutionaalisena uudistuksena Korkman esittää pankkiunionia, jonka tehtävänä on vakauttaa eurooppalainen rahoitusjärjestelmä oikeanlaisia kannustimia luomalla. Ainoa ero esimerkiksi Euroopan komission esittämiin ratkaisuihin on se, että Korkman ei usko talouspolitiikan sääntöihin samassa mitassa kuin esimerkiksi talouskomissaari Olli Rehn (ks. Rehn 2013).

Vaikka Korkman ymmärtää EMU-regiimin olevan "kovasti kallellaan keskuspankin ja finanssipolitiikan kurinalaisuuden suuntaan”, hänellä ei 
näytä selvästikään olevan halua rakentaa vaihtoehtoista eurojärjestelmää. Esimerkiksi sellaista, jossa työllisyys ja nopea kasvu olisivat talouspolitiikan ensisijainen tavoite. Tämä on hieman omituista, sillä Korkman tuntuu olevan huolissaan euroalueen syvästä taantumasta ja suurtyöttömyydestä.

Korkman ei suosittelekaan esimerkiksi euroalueen laajuisten kysynnänsäätelyinstituutioiden luomista ja paluuta toisen maailmansodan jälkeen Euroopassakin harjoitettuun keynesiläiseen täystyöllisyyspolitiikkaan. Tällaista ovat ehdottaneet jälkikeynesiläiset taloustieteilijät, kuten esimerkiksi James Kenneth Galbraith (ks. esim. NachDenkSeiten 2013). Sen sijaan Korkman suosittelee elvyttävää finanssipolitiikkaa niille valtioille, joilla on vielä mahdollisuus rahoittaa alijäämänsä markkinaehtoisesti. Kysynnänsäätelyä on siis harjoitettava tilapäisesti ja silloinkin markkinakurissa ja -nuhteessa.

Jos esimerkiksi Saksa tai Suomi eivät tällaista talouspolitiikkaa halua harjoittaa, Korkmanin mielestä tämä on hyväksyttävä. Laajemmat kysynnänsäätelytoimet, kuten heikoimmille talousalueille suunnatut julkiset investoinnit sekä tulonsiirrot, hän tyrmää ennen kaikkea siksi, että ne voivat johtaa budjettivallan väärinkäyttöön sekä taloudelliseen tehottomuuteen. Korkman ei siis usko euroalueen pystyvän harjoittamaan demokraattisessa ohjauksessa tarkoituksenmukaista ja kaikkia jäsenmaita tasapuolisesti hyödyttävää finanssipolitiikkaa, jolla olisi myös legitimiteetti kansalaisten silmissä. Korkmanin onneksi nykyinen ja hänen mielestään ilmeisesti kiveenhakattu Euroopan Unionin perussopimus kieltää EU-budjetin alijäämät, yhteiset velat sekä keskuspankkirahoituksen, jotka olisivat välttämättömiä tehokkaan kysynnänsäätelyjärjestelmän luomiseksi.

Lopulta Korkmanin Euroopan talous- ja rahaliitolle tarjoama tulevaisuus on synkkä ja saa varmasti monet edelleen esittämään kysymyksen, "miten EMU:sta pääsee pois". Laittamalla toiveensa pankkiunionin, markkinoiden ja talouskurin varaan, Korkman hahmottelee parhaassakin tapauksessa pitkittyvän suurtyöttömyyden ja hitaan talouskasvun euroaluetta. Siksi Korkmanin EMU:lle on syytä etsiä vaihtoehtoja esimerkiksi juuri chartalistisesta ja jälkikeynesiläisestä talousajattelusta. 


\section{Kirjallisuus}

Frankel, Jeffrey ja Rose, Andrew K. 1997. Is EMU more justifiable ex-post than ex-ante. European Economic Review, 41, 753-760.

Godley, W.ynne 1992. Maastricht and All That. London Review of Books, 14:19, 3-4.

Godley, Wynne. 1997. Curried Emu: the meal that fails to nourish. Observer, 31 elokuuta 1997.

Goodhart, Charles A.E. 1997. One government, one money. Prospect, 20. maaliskuuta 1997.

Goodhart, Charles A.E. 1998. The two concepts of money: implications for the analysis of optimal currency areas. European Journal of Political Economy, 14:3, 407-432.

Korkman, Sixten. 2013. Euro - valuutta ilman valtiota. Helsinki: Taloustieto.

Mundell, Robert. 1961. A theory of optimum currency areas. American Economic Review, 51:4, 657-665.

NachDenkSeiten. 2013. James Galbraith im Gespräch. http://www. nachdenkseiten.de/?p=18147 [Luettu 6.11.2013]

Rehn, Olli. 2013. Valtioton valuutta ja kansallinen etu” Helsingin sanomat, 24. lokakuuta 2013.

Schumpeter, Joseph A. 1954. History of Economic Analysis. Oxford: Oxford University Press.

Wray, L. Randall. 1998. Understanding Modern Money. Cheltenham: Edward Elgar. 